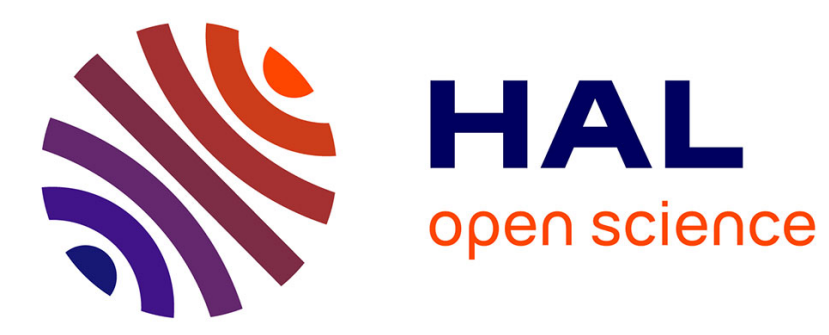

\title{
Wind Power and the Emergence of the Beauce Landscape, Eure-et-Loir, France
}

Alain Nadaï, Olivier Labussiere

\section{To cite this version:}

Alain Nadaï, Olivier Labussiere. Wind Power and the Emergence of the Beauce Landscape, Eure-etLoir, France. Landscape Research, 2015, 40 (1), pp.76-98. 10.1080/01426397.2013.784732 . halshs00762365

\section{HAL Id: halshs-00762365 \\ https://shs.hal.science/halshs-00762365}

Submitted on 20 Dec 2018

HAL is a multi-disciplinary open access archive for the deposit and dissemination of scientific research documents, whether they are published or not. The documents may come from teaching and research institutions in France or abroad, or from public or private research centers.
L'archive ouverte pluridisciplinaire HAL, est destinée au dépôt et à la diffusion de documents scientifiques de niveau recherche, publiés ou non, émanant des établissements d'enseignement et de recherche français ou étrangers, des laboratoires publics ou privés. 
Wind Power and the Emergence of the Beauce Landscape (Eure-et-Loir, France)

Alain Nadai ${ }^{1}$

CIRED - Centre International de Recherche sur l'Environnement et le Développement Jardin Tropical

45 bis avenue de la Belle Gabrielle

\section{NOGENT-SUR-MARNE Cedex}

E-mail : nadai@centre-cired.fr

\section{Olivier Labussière}

CIRED - Centre International de Recherche sur l'Environnement et le Développement Jardin Tropical

45 bis avenue de la Belle Gabrielle

94736 NOGENT-SUR-MARNE Cedex

E-mail : olivier.labussiere@centre-cired.fr 
6 Wind Power and the Emergence of the Beauce Landscape (Eure-et-Loir, France)

\section{Abstract}

In 2003 wind power arrived massively in the Beauce (at the outskirts of the Parisian basin). This article follows the evolving practice of landscape planning over the course of wind power development in this region of France. Our analysis suggests that landscape is regulated through practices, discourses and aesthetic codes, which define what is important about landscape and attempt to protect it. It shows that wind power not only affects existing landscapes, but also challenges the working of these underlying practices and discourses, triggering the emergence of new codes. By calling for a renewal in the way in which we regulate and experience our landscapes, wind power enables us better to understand the way in which the energy transition might raise issues about landscape protection.

\section{Keywords}

Planning - wind power - actor network - aesthetic codes 


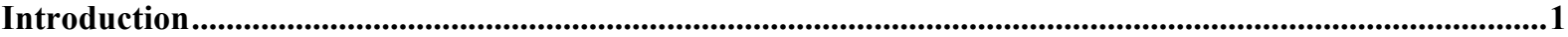

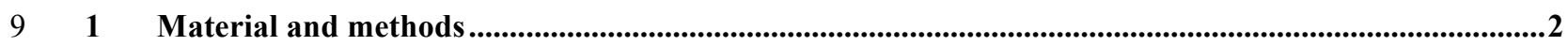

102 Before wind power: Chartres Cathedral, centre of a state-landscape ................................................3

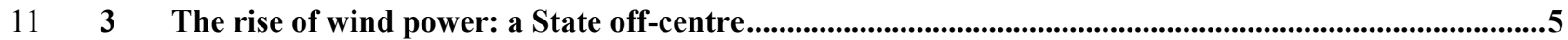

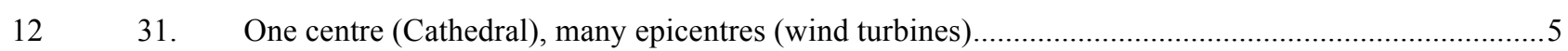

13 32. Capturing epicentres (photomontage), penetrating the landscape ................................................6

144 Re-centering the state-landscape: calling upon the Beauce .....................................................................

$15 \quad$ 41. Including the Beauce landscape in a planning approach...........................................................

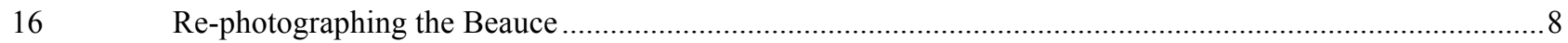

$17 \quad$ New principles and new tools for planning the Beauce landscape .......................................................

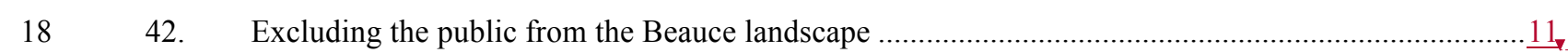

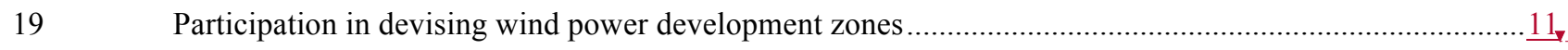

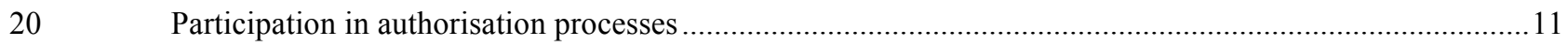

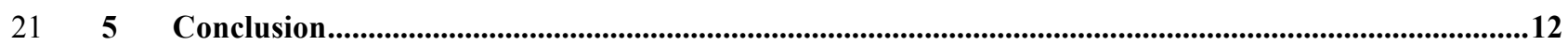

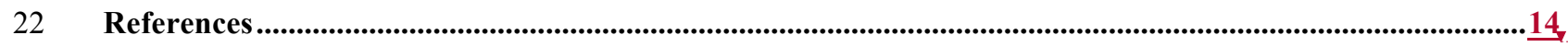

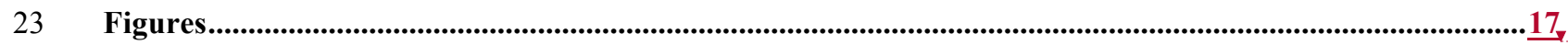




\section{Introduction}

'We are in the newly finished building of the Ministry of Culture. Civil servants in charge of heritage and landscape protection have come from all French regions (departments) to attend a national meeting on wind power. I have been invited to give a talk on wind power and sustainable development. The room is full. The atmosphere is highly charged after a reportedly tense morning session. The central administration is in the hot seat. It is time for the civil servant from Eure-et-Loir (at the outskirts of the Parisian Basin) to give an account of her experience with local wind power. While commenting on what she conceives 'also' to be a clear case of failed policy (implicitly referring to the discussions of the morning session), her first slide ( a map) is on the screen. A bright red, radiating figure is at the centre. It pictures what should have been protected from wind power but was not: Chartres Cathedral. The Cathedral literally irradiates the surrounding landscape, la Beauce, here made up to resemble an urchin-like, fully geometric figure: in some ways a translation of an open landscape, a landscape under the influence of the Cathedral. The figure is not only instructive in its size and presence on the screen (the room has suddenly become reddish); it is also striking because of the approach to landscape to which it bears witness. The Cathedral assumes a solar mode of existence, endowing its surroundings with its presence at the centre. It points as much to a landscape that has been denied under this "failed policy" approach as to a landscape that will have to be taken into account once wind power has genuinely been made part of landscape policy.' (field notes, Paris, July 2007).

This paper has been inspired by that reddish instant. Beginning in 2002, wind power arrived massively [I don't see the problem with this word.] in the Beauce (department of Eure-et-Loir, at the outskirts of the Parisian Basin). By 2007, the department of Eure-et-Loir already had one of the largest wind power capacities in France: 444 MW were approved (incl. $231 \mathrm{MW}$ in use in 2007), which translates to about 222 $2 \mathrm{MW}$-turbines ${ }^{2}$. This made the region into a central issue for the administration. Yet, instead of triggering a geographical extension of previous landscape protection in the Beauce, wind power challenged existing routines of (mainly visual) landscape protection. The scale and number of turbines hampered the administration from continuing to rely on the usual planning categories, such as foreground and distant landscape, patrimonial and non-patrimonial landscapes. In this process, La Beauce, an open field landscape with no heritage value whatsoever for the French state [I note that here 'state' is not capitalized. Decide where and when it should (for special emphasis) or should not be capitalized and revise accordingly.], emerged as a landscape deemed worthy of protection. Thus, beyond the specific case study, this paper is about a process through which new ways of representing and valuing landscape might emerge through planning. As such, it bears upon upcoming issues in landscape studies: 'landscapes of energies' (Nadai \& van der Horst, 2010b) is a term that has been used to point to the need for observing and analyzing the processes by which our landscapes will evolve in the course of the energy transition.

Landscape issues in relation to wind power have been important in France and the UK since the take-off of this kind of energy in these countries in the early $2000 \mathrm{~s}^{3}$. Today they also occur in other European countries, such as Denmark and Germany, currently famous for their successful 'civic' model based on local ownership of wind farms (Bolinger, 2005; Meyer, 2007; Nielsen, 2002; Möller, 2010). A striking feature in social science literature on wind power development is the uneven consideration of landscape issues. Some analysts have attempted to relate landscape issues to visual impact through quantification (Bishop 2002; Möller, 2010). Others have discussed landscape issues in relation to the extent of public consultation and deliberation in planning (Ellis et al., 2010; Fisher \& Brown, 2009, Wolsink, 2010; Toke et al., 2008; Zografos \& Martínez-Alier, 2009; Gee, 2010), eventually pointing to the ways in which landscape was represented in planning processes (Cowell, 2010; Nadaï, 2012; Nadaï \& Labussière 2009 \& 2010; Labussière \& Nadaï, 2011; Jolivet \& Heiskanen 2010).

We expand these analyses by considering the ways in which wind power development can induce changes in the manner landscape is protected and regulated. Planning processes provide an arena for following and understanding such changes. Hence we do not attempt, for instance, to assess the impact of wind power

\footnotetext{
Between December 2002 and October 2006, the size of the projects ranged from 1 to 10 turbines, with an average project size of 4 turbines (145 turbines, 35 projects) (DDE, 2006).

${ }^{3}$ For France, see, for instance, Legrand, 2002; Nadaï, 2007. For the United Kingdom,, Cowell, 2009; Toke 2005.
} 
development on the perception of landscape by local inhabitants or to quantify the visual impact of wind power on landscape. Instead we follow the evolving practice of landscape planning over the course of wind power development in a French region so as to understand the extent to which this development triggers changes in the way planners approach and implement landscape protection.

The tensions between wind power development and landscape protection have a cultural dimension (Nadaï et al., 2010). In France, landscape protection has traditionally been articulated in terms of visual relations and scenic landscapes. A genuine geometry of visual relations ended up underpinning the French state approach to landscape protection. Co-visibilities between new developments and landmarks, considered to be of heritage value by the French state, are a key category for governing [Some might think this verb odd here and prefer one like 'regulating'. But it seems to me that you mean to evoke the relevant connotations of 'govern'.] the landscape. Thus French landscape protection is both centralised (under French state responsibility) and centred in visual relations and heritage elements. Since industrial wind turbines are decentralised infrastructures that are visually perceptible from a distance, especially in open landscapes, it will come as no surprise that the development of wind power puzzled French landscape planners.

As suggested by this paper's opening quotation, the case of Eure-et-Loir is not an exception. Many French departments faced a similar challenge between 2000 and 2007. Eure-et-loir may even be looked upon as a paradigmatic case study: in the visually open space surrounding the Chartres Cathedral - a major French landmark - the issues of decentring that we have mentioned acquire a clear, spatially readable translation: abandoning a perspective exclusively attached to the Cathedral is equivalent to decentring landscape protection.

In the first part of this article we present the material and method $(\S 1)$. In the second part, we briefly analyse the French tradition of governing the landscape, which proceeds through the classification of landscape elements as part of national heritage and through the encoding of the visual relations between these heritage elements and their surroundings. For reasons that will become apparent in the analysis, we call this tradition the French 'state-landscape'. We then analyse how the emergence of wind power challenged this tradition in the Eure-et-loir and enticed local planners to change planning practices $(\S 2)$. In the third part, we detail the processes through which the local administration adapted its approach to landscape protection by abandoning a perspective exclusively attached to the Cathedral and by devising new concepts and tools for planning wind power $(\S 3)$. In the last section, we discuss the political dimension of this change, particularly by looking at who is allowed (or not allowed) to participate in different processes, such as establishing a photographic observatory for the Beauce landscape; devising wind power development zones and issuing permission for wind power project (§4).

\section{Material and methods}

The analytical categories we rely upon in our exploration of the Eure-et-Loir wind power and landscape planning process are familiar from Actor-Network-Theory. We conceive of both technology and landscape as a heterogeneous network made up of humans and non-humans (Marvin, 1988; Law, 1992; Bijker \& Law, 1994; Latour, 2005). Landscape as a heterogeneous network is a material and social entity. It is a material realm made up of trees, hills, valleys, housing. It also has an existence as maps, graphic elements, discourses, norms, landscape regulations, planning practices and notions, the practice and perceptions of its daily inhabitants. Our analysis pays attention to networks of actors, to conventional discourses, to the ways in which landscape representations can emerge in these discourses or in planning documents, to the materiality of these representations (for example, graphs, planning documents, laws) and to the practices associated with them (for example, circulation, networking, concerted decision-making, field-work practices). Our work is based on written and graphic documents (for example, planning and policy documents, administrative archives), field observation and face to face qualitative interviews (20) with state ministerial field services (for example, in environment, equipment, industry and energy), local mayors, territorial organizations, local NGOs and wind power developers engaged in the development of wind power projects. We conducted the interviews in two campaigns during March and September /October, 2008.

Far from putting forms on one side and practices on the other, our approach is developed along a theoretical tension in geography and landscape studies between representational and non-representational approaches (see, for example, Wylie 2007 or Nadaï \& Van der Horst, 2010b for a synopsis of this issue). It 
simultaneously focuses on the appearance of the forms, the content of the discourses and the practices of landscape planning in order to follow the way in which the development of wind power challenges the current discourses and practices of landscape protection in the Eure-et-Loir.

In order to follow these changes and to analyse their political dimension, we rely on what Rancière calls the 'Distribution of the Sensible' (Rancière, 2000) ${ }^{4}$. This concept points to a 'system of a priori forms determining what presents [Shouldn't the verb here be singular?] itself to sense experience' (Highmore, 2011: 96) and demarcates those experiences which will be possible for us to share and those which will not. It is an a priori categorization of this realm that underpins our capacity to experience it and to share the way in which we experience it. Sense experience is therefore endowed with a collective dimension: it can be captured and framed so as to exclude certain types of (landscape) experiences. Rancière's approach thus paves the way for a political analysis of the manner in which landscape experience is orchestrated. In Highmore's words: 'The social, for Rancière, is the orchestration of time and spaces, of sense and nonsense. It is the sensual, material realm that demarcates what is visible and what remains invisible, what gets heard as speech and what remains noise (who is heard and who is not)' (Highmore 2011: 96-97). Distribution implies inclusion ${ }^{5}$ in and/or exclusion from the process of defining what ought to be sense experience (landscape). Inclusion means distributing in the sense of sharing the sensation. It indicates a common understanding of or feeling for a given experience or realm (in our case, wind power landscape). Experiences that are endowed with this quality have somehow been submitted to a process of translation, networking and standardization, which makes possible their being shared. Exclusion means distributing in the sense of dividing modes of experiencing realms between those that can claim to be shared or voiced and those that cannot. Accordingly, we discuss inclusion and exclusion in section 4 by analysing the projectauthorisation processes that underlie the assemblage of wind power landscape. We look at the set of entities and actors who are allowed or not allowed to participate in different processes - for example, in the establishment of a photographic observatory for the Beauce landscape; devising wind power development zones and issuing permission for wind power project [This is a literal repetition of phrases in the final sentence immediately preceding the present section. Vary or drop?]- which underpin the emergence of the new wind power landscapes. We also look at the norms, codes, conventions and practices which frame these processes and decide the legitimacy of the diverse arguments that are voiced by stakeholders.

\section{Before wind power: Chartres Cathedral, centre of a state-landscape}

The Beauce has historically confirmed its status as a major agricultural area by land consolidations and mechanisation. This «beau ce» (literally 'pretty this'), which Gargantua praised as a place for good living (Rabelais, 1534), is today often considered of low landscape quality, especially by non-natives. Industrial cultures have replaced sheep grazing. They shape an open, almost abstract space, covering about 5,740 square kilometres southwest of Paris, punctuated by church steeples, villages and small valleys in the west. The northern part is dominated by the imposing and symbolic presence of the Cathedral Notre Dame de Chartres.

\section{Figure 1: View of Chartres Cathedral (Picture. T. Morinière)}

This presence is noticeable up to $20 \mathrm{~km}$ away. It has benefited from constant State attention. In 1997, it was placed under a new regulatory tool aimed at preserving the views of the Cathedral: a landscape directive. The 'Cathedral Directive' was opposed by several elected officials because the local representative of the French government, the Prefect of Eure-et-Loir, had taken local politics insufficiently into account. Blocked at the project stage, the Directive draft was nevertheless circulated in planning documents: 'It's a project that has ended up having a ghostly existence [...] everyone knows it. Its perimeter is included in the planning documents. In this way it has ended up carrying weight ${ }^{6}$.

\footnotetext{
The term 'Sensible' is used in the English translations and analyses of Rancière's work (Highmore, 2011; Sayers, 2011). In order to make clear that the term is an idea borrowed from Rancière and not another meaning of the adjective 'sensible', we write capitalize it.

The terms 'inclusive' and 'exclusive' are derived from the English translation of Rancière (Highmore, 2011; Sayers, 2011).

${ }^{6}$ Landscape Advisor, Diren Centre, March $6^{\text {th }} 2008$.
} 
Figure 2: Cartographic representation of the (project of) Cathedral Directive (Source: Schéma de Cohérence Territorial de l'aire urbaine de Chartres, 2004). [The green radiuses represent views from and to the cathedral and were supposed to be protected against any construction project: they are illustrative of the traditional French visual approach to landscape protection.]In order to provide visual protection of the views from and to the monument, the cartographic representation presents the Cathedral in the form of cones radiating into the countryside (Figure 2). The 'Cathedral Directive' is symptomatic of the French State's approach to landscape (Dupont, 1997) in that it emphasizes the visual landscape and its rather tenuous relationship to local interests. This policy of visual landscape is partly rooted in the administrative approach to monuments and their surroundings, which dates from the early twentieth century. It consists of two traditions. The first goes back to the protection of historical monuments (Laws of $1913^{7}$ and $1943^{8}$ ), based on the concepts of "surroundings" 9 and 'conservation of monumental perspective" ${ }^{, 10}$. The second goes back to the protection of natural monuments and sites (Laws of $1906^{11}$ and 1930), which aimed at protecting those deemed to be of heritage value ${ }^{12}$ from any 'offence against the spirit of the place'. Although the impact of this dual tradition has not been quantitatively significant as to the portion of the territory covered $^{13}$, it has provided grounds for what might be called a state-landscape. By this we mean a type of naturalization and institutional objectification of the landscape that has evolved since the $1970 \mathrm{~s}^{14}$ and expanded into a diffuse body of laws about environment, architecture and urbanism

Three concepts have been at the basis of this state-landscape: 'heritage', 'co-visibility' and 'surroundings'. The idea of 'heritage' refers to sites or monuments considered sufficiently important to be part of the French national heritage, that is, part of the 'common good'. Assigning designation was originally the responsibility of the State and was progressively extended to include a consultation process, notably through public inquiries. The concept of 'co-visibility' refers to the fact that a site/monument deemed to be of heritage value and a new project or projects are visible from some point of view, either mutually or singly. This concept has lost some of its exclusive character in the definition of landscape, but it still guides administrative decision-making. Finally, the idea of 'surroundings' arises from the premise that the perception of a monument is conditioned by its immediate environment. It contributes to defining visibility by setting a geometrical definition for a state-declared area round the monument. Initially circular (a 500 meters radius area), its contour has been changed (successive laws in 1983 and 2000) in order to adapt it to local situations as well as to extend it to protect heritage landscape (in 1993). Planning this area has also become more open to public participation and has evolved from protection to management by including considerations such as 'charters' or 'good practices' in project development.

Such a legislative arsenal proves the importance for the French State of both the visual approach and its delineation in the plan (2D representation) as ways of translating landscape into a 'public good'. The (sight) line (in the plan) is endowed with the power of ruling, if only because it delineates the space (sub-territory, state-declared area) in which certain branches of the administration are vested with the power of procedural veto for project development. When this is not the case, the administration relies on the co-visibility criteria so as to bring the surroundings into existence as landscape elements: 'It's a matter of sight. From the monument, we look at what is happening around it, and from the surroundings we look at what happens to the monument; it works together ... it's like a jewel and its box ${ }^{15}$.

40 The primacy of the visual and the geometry of space thus contribute to endowing this state-landscape with

\footnotetext{
${ }^{7}$ Law of December 31, 1913 about 'Monuments historiques'.

${ }^{8}$ Law n ${ }^{\circ} 43-92$ of February 25, 1943.

${ }^{9} \mathrm{Cf}$. articles 13 bis and 13 ter of the law of December $31,1913$.

"Law of July 13, 1911, whose legal content is now in art. R111-21 du code de l'urbanisme.

${ }^{11}$ Law of April 21, 1906, put into final draft in the law of May $2^{\text {nd }} 1930$, today codified in the articles L. $341-1$ à 22 of the Code de 1'Environnement. 'Sites inscrits' and 'sites classés' are the two types of protected areas according to heritage considerations. 'Inscription' implies a will to keep the site unchanged, whereas 'classification' imposes only a duty of informing the administration of any project that could affect the classified area. These ideas were made final under the Law of May 2, 1930 and written into the French code for the environment. The 1930 law is usually referred to as being in the tradition of 'monumental landscape': it extended to landscape a type of protection that was already in place for monuments, thus implicitly 'valuing' landscape as if it was part of the French monument heritage.

${ }^{12}$ In fact, the Law of March 30, 1887 instituted the idea of historical heritage. The 1906 law instituted the idea of natural heritage by protecting the natural monuments and sites.

${ }^{13}$ By the end of the $1990 \mathrm{~s}$, protected sites and important landscapes encompassed $2 \%$ to $3 \%$ of the French territory.

${ }^{14}$ For a detailed analysis, see Barraqué (1985) on the emergence of a landscape administration.

${ }^{15}$ Interview with the Aveyron SDAP, December 14, 2006.
} 
a factual dimension, which in turn legitimises its administrative takeover. The state-landscape punctuates the French territory; it is a landscape made up of a multitude of state-declared areas resembling isolated and irradiating figures. It is these irradiating figures that industrial wind turbines suddenly connect through the far-reaching co-visibilities imposed by their size.

\section{The rise of wind power: a State off-centre}

In 2001, the adoption of fixed tariffs for wind electricity secured significant profits for wind power developers in France. It induced them to prospect rural areas intensively in search of sites on which to set up turbines. This led to unprecedented pressure on mayors and local administrations. As the usual construction permit proved irrelevant for arbitrating wind power projects, local authorities responded by devising ad hoc planning schemes. The development of this new and decentralized energy nurtured a lively and active opposition to the technology at both the local and the national level, partly boosted by the feeling that wind power policy was exclusively profit-driven. It was also the occasion of a major controversy over whether or not to decentralize French energy policy. Detailed analysis of the parliamentary debate shows that multiple strategies - including full centralisation (as a means of direct control) or full decentralisation (as a means of putting energy policy in the hands of the then vigorous local opposition) - were successively undertaken by some parties in order to limit wind power development (Nadaï, 2007). As far as planning is concerned, the outcome was a compromise solution in the form of Wind Power Development Zones (WPDZ), which are proposed by local communities but validated by the local representative of the State: the department prefect. Unlike the German or Danish wind power zones, WPDZ are not planning zones per $s e$, but electric contracts that then become planning incentives. They are not translated into urban planning documents (a process which would have involved town councils). Although wind power projects do not have to be located in a WPDZ to be granted a construction permit, they can benefit from fixed tariffs only if they are located in a WPDZ. As such, WPDZ are a type of half-way decentralisation, a de-centring ${ }^{16}$ of energy policy that is symptomatic of the ambivalence found in French political circles and institutions when it comes to the development of (decentralised) renewable energies.

Administrative authorisation for WPDZ as well as for individual projects involves the various ministerial field services (environment, heritage, energy, road and infrastructure). The local (departmental) branch of the Ministry of Culture (SDAP), in charge of landscape and heritage protection, may have an important say in the authorisation process ${ }^{17}$. The regional environmental field service (Diren), however, has a key role to play as coordinator of the overall administrative process and with respect to notification. While project authorisations tend to follow procedures that have been stabilised since the adoption of fixed tariffs, WPDZ processes have been more flexible. Their devising under the supervision of local communities and intercommunalities have in some cases allowed them to involve non-state entities, such as a local NGO's or territorial entities (Parc Naturel Régionaux). The extent to which each of these different entities has shaped wind power development depends on local configurations and political will, especially on the part of the prefect of department.

\section{One centre (Cathedral), many epicentres (wind turbines)}

In the Eure-et-Loir, wind power build-up was so rapid (in 2003, 12 permits were granted; in 2004, again 12 ; and in 2005,22 ) that local administrations often lacked the time for in-depth inquiry and fieldwork. Developers knew the field better than the administration, thanks to intensive prospecting: 'It works like archaeology, where you discover treasures while working in the field ... We discover the potential of our region through the developers' impact studies ${ }^{18}$.

Between 2003 and 2005, the Cathedral provided strong and central arguments for not authorising projects that would be sited too close to Chartres to avoid 'visual competition' or 'cluttering up the visual environment of the monument ${ }^{19}$. Moreover, in the Beauce, the notifications sent by Diren ${ }^{20}$ to wind power

\footnotetext{
${ }^{16}$ Or déconcentration in French, meaning that, though still under State control, it is approached from the periphery, closer to the local level.

1 The Ministry has a veto power on projects if these are located within a perimeter of 500m around the heritage site. Otherwise, its advice is only consultatory. As wind turbines create co-visibilities that are far more extensive than the approved perimeter, the Ministry often has little decision-making power (consultatory) in authorising wind power projects.

${ }^{18}$ Interview with the Diren Centre, 2006.

${ }^{19}$ Diren Centre, November 23,' 2005, technical advice about the PC 1600500005 (Francourville).
} 
developers referred to landscape and spatial problems such as co-visibility (with protected sites or, to a lesser degree, housing areas), encircling of villages and the spatial display or inter-distance between wind farms.

But wind power overflowed the boundaries of the state-landscape (as previously defined in $\S .1$ ) in two important ways. First, the tools for legal inquiry introduced by recent legislations in relation to wind power (impact studies, construction permits, public inquiry) opened landscape assessment to a multiplicity of dimensions that encompassed and went beyond the sole visual dimension of the state-landscape (natural environment, wildlife, heritage, noise pollution and public health issues). As stated by the Ministerial guide on 'Good practices for Impact Studies': 'It would be pointless to try to integrate wind farms into the existing landscape. Landscape preservation in the classical sense is neither possible nor desirable. The challenge is rather to aim at a type of landscape development' (cf. ADEME and MEDD, 2004:54). On the other hand, in the restricted field of visual landscape itself, wind power suddenly introduced multiple relations, complex and remote connections, which the traditional geometrical zoning could no longer properly regulate. 'Higher than the cathedral's spires ${ }^{21}$, the turbines acted as genuine sources of visual interactions. They progressively composed a complex net of visual epicentres that landscape protection could neither ignore nor accommodate within the state-landscape approach. As the Eure-et-Loir statelandscape advisor pointed out, "Chartres is a strong reference point for the whole sector... People call "Beauce chartraine" the overall sector dominated by the Cathedral. The problem is that the turbines come and disturb this very idea. At bottom, that's what is at stake [...] Am I the reference point or am I not? ${ }^{22}$.

The photomontages, which were included in the impact studies, constituted the visual representation through which this new visual landscape was shared and circulated. They were the representations through which turbines were endowed with a visual existence as new epicentres of the Eure-et-Loire landscape.

\section{Capturing epicentres (photomontage), penetrating the landscape}

The photomontage has been presented by the French authorities as a flagship tool for assessing the impact of wind power on landscape and as an 'excellent basis for running concerted decision-making processes' (cf. ADEME and MEDD, 2004: 68). According to good practices, it aimed at simulating the presence and integration into landscape of a future wind farm, as perceived from different points of view. It was thus designed to translate the presence of wind power into landscape as experienced in situ and to circulate this translation. Yet making a photomontage relied on a set of operations (for example, choice of the view, shooting angle, technical parameters such as focal lens, colours, contrast and brightness, and mounting technique) which paved the way for various biases, with the result that photomontages could easily be devised so as to serve the interests of those who developed them. The gradual spread of visual simulation software came to diminish some of these biases ${ }^{23}$, but could not of course guarantee faithful translation of the in situ experience.

A review of the administrative assessments of wind power projects in the Eure-et-Loir between 2003 and $2006^{24}$ shows that it was a period during which the local administration heavily relied on photomontages for decision-making. The administration also endowed this tool with a normative dimension that photomontage could not do justice to given the then existing relation between fieldwork, developers and administration. In practice, the local administration lacked the material means for a systematic follow-up of inquiry in the field. It had to rely on the wind power developers' capacities for exploration, which had been boosted by the large profit margins yielded by the fixed wind power tariffs. Moreover, in spite of the large number of projects approved, the actual deployment of turbines was slow ${ }^{25}$. The administration lacked field-references that would enable it to experience the presence of wind turbines in the landscape and so the cumulative effects of the approved projects. In situ experience would have been needed to formulate

\footnotetext{
${ }^{20}$ Analysis of administrative notifications, 34 wind power projects, between 2003-2006, based on the construction permits files made available by the Eure \& Loir DDE.

${ }^{21}$ Title of the September 21, 2005 issue of the local news paper La République $d u$ Centre on the day of the erection of turbines in the wind farm at Bonneval, thirty kilometres from Chartres.

${ }^{22}$ Interview with the State landscape advisor, Region Centre, March 6, 2008.

${ }^{23}$ Here we find at work the mechanical objectivity described by Lorraine Datson and Peter Galison (1992).

${ }^{24}$ Analyis of administrative notifications between 2003-2006 (cf supra).

The first wind farms were actually built in 2006. In the autumn of 2006 about 35 projects (145 turbines) had already been authorised.
} 
requests in adequate terms and induce developers to convey the wind power landscape through photomontages.

The first wind farms were erected between 2005 and 2006. A new administrative officer with a background in social science, hereafter called Harold, took charge of these questions at the Diren Centre (which administers the entire Centre region, including Eure-et-Loir, Loiret). Photomontages still played a decisive role, but the administrative notifications indicated a twofold evolution. On the one hand, the administration appeared to grow increasingly critical of the photographic medium itself, while still admitting the relevance of photographic realism for objectivity. On the other hand, new issues relating to the increasing complexity of the landscape recurred again and again in the notifications. For instance, they pointed to visual interactions between wind farms, to turbines close to dwellings, and to a 'visual saturation' in the south of the department. Standards also became more exacting with respect to the Beauce as an entity and as a landscape, leading to the refusal of some projects: 'If all these wind farms $[\ldots]$ become reality, this sector of the Beauce will be saturated with turbines. The situation doesn't appear to us to be acceptable, whether because of its impact on the inhabitants, on wildlife or on the landscape, 26 .

Overall, in this period of the massive increase of wind power projects in the Eure-et-Loir, photomontage failed to communicate both the state-landscape and the presence of wind power in the Beauce landscape. These limitations were particularly rooted in the increased exploratory capacities given by wind power tariffs to developers, who could thus use photomontage to take possession of the visual landscape.

\section{Re-centering the state-landscape: calling upon the Beauce}

Two reports written by the local administration bear witness to its response during 2005 (cf. Diren, 2005; Bonneaud, 2006). The first report used a cartography of the visual impact of wind farms approved or under administrative assessment (cf. figure 3) in order to indicate the emergence of a 'Wind Power Beauce', where the 'verticality of the turbines' would be predominant, and to distinguish between the 'Traditional Beauce' (open field landscape, horizontality) and the new Beauce. This was the very first time that Beauce was mentioned as a landscape deemed relevant to policy attention: 'There will remain hardly a sector of the Beauce left without a view on turbines, ${ }^{27}$. The second report refined this statement by analysing illconceived cases: villages with distorted skylines and an overwhelming presence of turbines as seen from some settlements. The entire approach to the regulation of wind power development was being progressively questioned. 'The Eure-et-Loir has been a testing ground [...]. It is the failure from which we must learn ${ }^{28}$.

Figure 3: Wind Power Projects construction permits (accepted or under administrative assessment) (10km landscape impact radius) (Source Diren Centre, updated 18/11/2005) [ In 2005, 44 wind projects had been granted construction permits; the local administration represented them on a map, assuming a $10 \mathrm{Km}$ visibility radius, and concluded that project authorisations and planning procedures had not properly regulated wind power development].

Focusing on isolated cases and considering the visual perception of wind power from inside the villages (the inhabitants' point of view) soon raised issues of political legitimacy for the administration (that is, the Diren Centre). As one Diren officer said: 'What gives us the right as an administration to go beyond the large-scale landscape where our action [as part of the French State] is legitimate [....]? All clues point to an absence of opposition to wind power in the Beauce ${ }^{29}$. In other words, if the French State, acting through Diren, has the right to protect the larger landscape, how could it speak for the people about their proximate landscape when the people do not themselves seem to experience the proximity of wind turbines as a problem? This enticed Diren to change strategy.

\footnotetext{
Diren Centre, March 24, 2005, technical advice.

Interview with the Diren Centre civil servant, March 6, 2008.

Idem. The Beauce covers about 5,740 square kilometers. It encompasses the departments of Eure-et-Loire, Loir-et-Cher and Loiret, that is, about $1 / 8$ of the Centre Region.

Ibid. At the end of 2008, one local NGO (kiproko; http://www.kiproko.info/GoogleEarth/Beauce.htm) opposed wind power development in the Eure-et-Loir. We have not inquired into the absence of opposition to wind power in this case study. However, some interviews indicate that industrial agriculture and farmers dominate the local politics in village and that wind power was perceived by local mayors as part of the private business of industrial farmers.
} 
There were signs in Diren's two reports that heralded the emergence of a 'larger' state-landscape. One of the recommendations of the first study pointed to the importance of 'not wasting space ${ }^{30}$ (for example, making existing projects denser). New concepts emerged such as the need for a distinction between the 'traditional Beauce landscape' and a 'Wind Power Beauce' ${ }^{31}$. Ultimately, the revolution at Diren consisted in reasoning on the scale of the 'Beauce as a unit' as well as in seeking new tools and a new approach for planning wind power.

Such a shift was all the more surprising as it rested precisely on the lack of concern for the landscape: 'Nobody cares [about the 'larger landscape']: our action is therefore legitimate ${ }^{32}$. 'Larger landscape' was put into a scale in which few individuals would feel committed to participate or for which they would express their spontaneous support. That the administration somewhat downscaled the landscape showed its distancing itself from the public: invoking public interest as a rationale for landscape protection was in fact a way to exit from local politics. Changing landscape boiled down to changing politics: 'It is as if our interest in the Beauce as a landscape had been aroused by the presence of wind turbines, which led us to rediscover landscape values ${ }^{, 33}$.

\section{Including the Beauce landscape in a planning approach}

\section{Re-photographing the Beauce}

Among the new tools developed to renew the approach to landscape was a photographic observatory aimed at acknowledging the rising interest of local planners in the Beauce landscape.

Since 1991, the practice of photographic landscape observatories has been part of the evolution of French landscape policy. It reached its methodological normalisation in a document recently published by the Ministry on Environment (MEEDDAT, 2008). The method aims at 'the constitution of a library of photographic sequences in order to allow for an analysis of [the] transformation of spaces [...] analysis that will be used as a tool to foster a favourable evolution of the landscape' (ibid., p. 6). Its principle consists in taking photographs of a given landscape and repeating observation of the sequence at a later time (constant framing, periodic repetition of the sequences, planned itinerary). 'Re-photography' is the name given to this practice and method. Instead of being a tool for classical comparison (before/after), it aims at setting the conditions for serial observation (constant framing, periodic repetition of sequences, planned itinerary). The photographic observatory preserves a memory of the evolution of landscapes, 'bringing to visibility the essential elements' of a territory (MEEDDAT, 2008, p. 33).

In 2007, Diren realised that a total of 35 new wind turbines had been authorised in the southern part of the central region (Indre department) ${ }^{34}$. As they would be installed between 2008 and 2010, Diren decided to launch a photographic landscape observatory to 'witness' 35 the rapid mutation of the Beauce landscape in this area: 'The idea is to observe the accumulation of wind turbines' ${ }^{36}$. At the time of our research, Diren was only initiating a preparatory phase. It nonetheless provided the occasion for fieldwork. Following the Diren Centre in this phase showed that (in spite of the absence of a photographer at this stage) the observatory not only served memory-keeping and synthesis, but also provided means for adjusting a situated perception of the future presence of wind farms in the landscape and for classifying evolution according to types.

Diren still had in its possession the impact studies and the photomontages provided by developers. In the autumn of 2008, an intern at Diren conducted the first fieldwork in order to locate photographic viewpoints for the observatory. He had collected the photomontages from the impact studies and located the

\footnotetext{
Diren, 2005: 83

Ibid: 11.

Interview with the Diren Centre civil servant, March 6, 2008.

Idem.

${ }^{34}$ Indre is in the southwest of the Beauce, not actually part of the department of Eure-et-Loir. However, the work observed and described in this area was for the administration an integral part of the planning process and the photographic observatory that covers the Beauce and the Eure-et-Loir.

Following of the Diren Centre fieldwork, May 16, 2008.

Idem, the Diren-Centre civil servant.
} 
corresponding viewpoints on a map. By combining deskwork and fieldwork, he was able to compile a list of the viewpoints and locate them on a map (as cones of visibility). Equipped with this preparatory map and colour copies of the collected photomontages, the intern, Harold and the Diren landscape architect then went into field. They literally followed in the developers' footsteps by selecting the most sensitive points of view they had identified. While no wind turbine was yet in place, visual landmarks (water tower, telephone relaying station) provided reference points in the landscape and on the map that allowed the civil servants to keep track of the locations of the future wind turbines. These points also conveyed a feeling of scale, enabling the officials to grasp the future presence of the turbines. Each point of view was the occasion of a discussion and exchange about in situ perception and experience, looking for the exact viewpoint that revealed the way in which the wind turbines would reshape the landscape. This experience was constantly checked against a location in the map, compared to the developers' photomontages, and standardised through a few indications for the photographer (framing, position in space, shooting angle). In this preparatory exercise, field experience was progressively bringing the photomontages into a new network by relating them to the map, the sites and their atmosphere. State officials were developing a counter-expertise about photomontages. A new State viewpoint was emerging, one that connected wind power landscape representation and planning procedures to the field. Fieldwork also enabled Diren to abandon a perspective attached to the Cathedral and shape a de-centred viewpoint in the landscape, a viewpoint that went beyond 'classified' heritage and landscape. This provided the administration with a situated experience of the Beauce landscape, with a language capable of potentially making it sharable - the 'Traditional Beauce' versus 'Wind Power Beauce' - and with a project to go ahead with.

\section{New principles and new tools for planning the Beauce landscape}

At the end of 2007, a wind power scheme was under development in the department of Loiret (next to Eure-et-Loir). Diren was invited to participate in it and started experimenting with the new principles, introducing Beauce as a 'larger landscape' into the planning categories: 'We must not think about one wind farm at a time, but approach things on a larger geographic scale and consider how to group farms together ${ }^{37}$. For Harold, the experiment with first permit authorizations in the area was very successful. 'We succeeded in designing an ideal wind power basin [...] All we needed then was to invent a label in order to say that this was what we also wanted to have elsewhere ${ }^{38}$. He saw the experiment as providing the basis for a model of regulation, which translated the Beauce landscape into two concepts and elements - 'wind power basins' and 'breathing spaces' - which enabled the administration to regulate wind power development in accordance with visual principles. In a basin, 'the wind farms are sufficiently close [to each other] to be perceived as an ensemble ${ }^{39}$. Complementary to the basins, the breathing spaces allowed the administration to '[confine and group] the wind turbines within well-defined spatial envelopes and to reduce their visual impact on the larger landscapes' ${ }^{40}$. Interviewed about 'breathing spaces', an officer said: '[...] when you look at the other side of the road, you have turbines, but they are in the distance, so you have this effect of breathing. It is this faraway [in French 'cet au loin'] that has to be protected [...] We do not define breathing spaces as zones where one sees no turbines; we define them as zones where the visual pressure of the turbines decreases ${ }^{41}$. This new approach also provided a solution for how to make new wind power developments compatible with both the preservation of the state-landscape and the already existing and planned wind farms.

Figure 4: Wind Power Development in the Loiret - Eure-et-Loir Wind Power Scheme, 2008 [The design of the Loiret planning scheme, which was concomitant with that of the Eure-et-Loir, gave the local administration with an opportunity to design wind power basins (light blue) and breathing spaces (orange

Interview with the Diren Centre civil servant, March 6, 2008.

Interview with the Diren Centre civil servant, October 3, 2008.

DDE du Loiret (Janvier 2008) Développement éolien dans le Loiret. Les orientations de l'Etat. "Vers la constitution de bassins éoliens ». http://www.loiret.equipement.gouv.fr/IMG/pdf/annexe_cle13e2d2.pdf

Idem.

"Interview with the Diren Centre civil servant, March 6, 2008.

In this quotation, the officer employs an unusual, grammatically incorrect but intentional use of the adverb 'au loin' (meaning 'faraway') as a substantive to translate the perception that this landscape conveyed 'a breathing effect' (sic: 'un effet de respiration'). This rhetorical form is not neutral. Nominalization literally turns the experience of 'breathing' into a landscape element, which was later to be translated into an (unusual) planning category: the 'breathing space'. 
stripes) which straddled the administrative border (top left of the map)].

1 During this period (autumn of 2007), a new prefect was nominated in the Eure-et-Loir. He declared 'that the department had already done enough for renewable energy in this country. There's no need to do more ${ }^{42}$. He also ordered the local administration to revise the Eure-et-Loir wind power scheme (issued in 2005) and to base the new scheme on 'harder standards'. ${ }^{43}$.

Figure 5: Landscape Sensitivity - Eure-et-Loir Wind Power Scheme, 2005 [In 2005, the first wind power scheme in the Eure-et-Loir was based on a visual approach and represented zonings for visual protection following the valleys, the frontier of the regional natural park (PNR, left part of the map) and the radius of the Cathedral Directive].

For Diren, this political event provided a window for enlarging the planning principles that had come out of the Loiret experience. The scheme was strengthened by various means $(20 \mathrm{~km}$ protection radius around the Cathedral, extending buffer zones around valleys), including the creation of three wind power basins in the south-east of the department. These three basins were separated by a zone of lower density called a 'breathing space'.

Figure 6: Landscape Sensitivity - Eure-et-Loir Wind Power Scheme, 2008 [ In 2008, the second wind power scheme included existing wind power basins (in light blue) and landscape sensitivities. These elements are represented by coarser graphic forms (figuring buffer zones, large circle around Chartres, in red). This is an attempt to account for the Beauce landscape and its large scale as well as to concentrate wind power development in the existing basins rather than to seek a detailed and territorial delimitation of zonings].

As this process was concomitant with that of the Loiret, it provided Diren with an opportunity to design wind power basins and breathing spaces that straddled the administrative border. This resulted in a coherent planning on the scale of the Beauce. The new Beauce basins and the breathing spaces did not outline zonings in a proper sense. They were translated in the map as somewhat shapeless forms that did not indicate geometrical or territorial areas and did not clearly delineate an inside and an outside (see figure 6). The design of these graphic forms was justified in terms pointing to sensation and visual experience in relation to the presence of wind power in the landscape. The terms called attention to the logic of the situation, such as the possibility of perceiving from a certain perspective an expanded Beauce landscape in which the presence of wind turbines could remain marginal. The administration's arguments against developers' attempts to propose new projects within these breathing spaces showed how sensation, as an experience of the presence wind power, continuously circulated between visual experience and planning: ' $[\ldots]$ there is a real physical boundary between the wind power basin and the breathing space [...] Going from Orléans to Paris by train or by state road 20, one sees all the turbines on one side all the way. They are all on the west side. To the east, one sees today a landscape without any turbines [...] We said we found it rather interesting to have an industrial wind farm landscape on one side and a more traditional Beauce landscape on the other ${ }^{44}$. While shifting to the 'larger' state-landscape, Diren was also changing its way of devising and organising this state-landscape. It was no longer based on metric relationships between heritage elements and their surroundings (radius, visual cones, co-visibilities), but on rhythms, contrasts (left side/right side of the road) and differences (the traditional Beauce/the Beauce of industrial wind farms). Because the approach had become less formal, it was more open to concepts such as density, saturation, breathing spaces (preserving a 'far away') and made it possible to introduce the language and practice of experience into the core of planning.

Loose lines, shapeless forms and experiential concepts, however, also made it harder to share the logic of planning with developers. Though a process seemed to be set in motion, it remained extremely fragile, as could be seen in developers' attempts to move into the planned breathing spaces. This seemed to call for a

Statement quoted by La République du Centre, July 10, 2008. Interview with the Diren Centre civil servant, March 6, 2008. Ibid.. 
form of sharing and legitimacy that went beyond the scope of a single administration.

\section{Excluding the public from the Beauce landscape}

\section{Participation in devising wind power development zones}

Wind power development zones (WPDZ) were the institutional setting in which the new planning scheme could have been brought under the umbrella of more open governance. WPDZ have to be proposed by groups of local communities and approved by the department prefect (see §3). The way in which they actually work after 2007 in different French departments has depended on the interplay between the political authority of the prefect and the initiatives of local communities and inter-communalities. Some prefects have imposed a political process by requiring all WPDZ proposals to be drawn up by several communities and turned in to the administration before new project authorisations would be granted (for example, Nadaï \& Labussière, 2009). Other prefects did not; they accepted that WPDZ processes remained technical and usually recycled the impact studies of individual wind power projects in a new administrative format, with no requirement of inter-communal participation or agreement.

In the Eure-et-Loir, the WPDZ processes followed this second route. Some were steered by the main land owners (farmers) and followed a rent-seeking logic, allocating wind power zones so as to satisfy individual demands in the community. Others worked along a purely 'technical' line, outsourcing the treatment of wind power issues to a private landscape company so as purportedly to avoid political tensions, but without devising landscape/territorial projects. In both cases, Diren was faced with difficulties in sharing the new visual landscape, either because of the 'rent seeking' logic or the limited means allocated to landscape companies for their work. The result was that local governance failed to provide the new wind power scheme with legitimacy.

\section{Participation in authorisation processes}

Procedures for project authorisation also failed to contribute to citizen participation in decisions on wind power development. Like many other local administrations when wind power started to take off in France $^{45}$, the Eure-et-Loir administration progressively divided the procedures for project authorization into two branches, called by the local officers themselves the 'technical branch' and the 'political branch'. The first branch covers the assessment of the construction permit and the impact study; the second includes a public inquiry (on the basis of the impact study, publicly posted in the town for a month) and the opportunity for citizens directly to petition the prefect. Both branches intersect at the level of the prefect, who gives a final 'political' decision on the basis of three types of evidence: the administrative notification (based on the construction permit and the impact study, usually coordinated by Diren), the report of a commissar (based on the public attendance and petitions during the public inquiry) and the direct petitions that any citizen can send to the prefect. Either side can appeal the decision of the prefect in the administrative court. In the case of wind power, this is often the case: either 'opponents' of wind power or developers appeal the final decisions. As a consequence, local ministerial field services have come to see their role in these processes as one of producing notifications that can resist judiciary attacks, so that prefects basing their decisions on these notifications have a chance of getting them confirmed in the administrative court.

These procedures have had three major consequences. The first is that they set an early interaction with developers while relegating public consultation to the political branch and to the last phases of the process, when projects have already been made final. As has been indicated in the planning literature (cf. Healey, 1997), this tends to form the public into opponents by giving it only the possibility of reacting to finalized options. Second, as far as landscape is concerned, administrative notifications anticipate the judicial process and base their arguments on categories and norms that are infused with judicial values. This landscape, which some officials have come to call the 'opposable landscape', is mainly made up of sites and monuments endowed with shared patrimonial values and comes down to what we discussed as the state-landscape in $\S 1$. Third, the procedures are a powerful way of objectifying decisions while keeping the public at a distance. In the early years of wind power development, officials eventually attended public

\footnotetext{
${ }^{45}$ Based on individual interviews by the authors in the 22 local environmental administrations during the autumn of 2006
} 
meetings on wind power projects. This experience proved very difficult, for they were faced with unsolved issues in wind power planning and policy, but were constrained to remain silent about projects under administrative scrutiny by their oath of secrecy. The result was that officials no longer attended such meetings, most of them admitting to having received instructions from their hierarchy not to do so. When questioned about the legitimacy of an assessment in the absence of any contact with the opponents or with the public ${ }^{46}$, they consistently referred to the 'political branch' as the body responsible for giving these parties a voice. Yet, as the 'political branch' ended up basing its decision on the (administrative) notifications of those same officials, the overall procedure has turned into a self-referential loop that ultimately implements the judicial norm. Public inquiries, presumably the place for the expression of public opinion, proved incapable of breaking this loop and conveying the opposing position. Most of these inquiries led to favourable notifications, with provisional to marginal project adjustments (size, siting of the machines; for an illustration of this, see Nadaï \& Labussière, 2009). The result has been an administrative procedure that not only focuses on the state-landscape, but also makes it objective and legitimate to do so: objective through technical advice and legitimate through an ill-functioning consultation process. The administrative process boils down to to a way of objectifying the political dimension of wind power by keeping the public and the expression of its views at arm's length.

In general, the absence of politics in the WPDZ processes and the procedural objectivity of administrative authorisations were double-edged. On the one hand, the processes were an attempt to more strongly bolster administrative decisions, political authority (prefects' authority) and make the state-landscape less debatable. On the other hand, by leaving experiential concepts and shapeless forms in planning with no other legitimacy than that of the local representatives of the State, they made the new state-landscape very vulnerable to being disregarded by developers. Ultimately, this led to a paradoxical situation in the Eure-etLoir when the absence of public opposition made it increasingly difficult for the local administration to legitimise any backlash against developers' strategies and their pressure to go ahead with new developments.

\section{Conclusion}

The case of Eure-et-Loir illustrates how the development of wind power can profoundly challenge an administrative and visual tradition of landscape protection. It suggests that landscape is constructed through discourses, codes and procedures which define what is important about landscape and attempt to protect it. It shows that wind power not only affects existing landscapes, but also challenges the working of these underlying discourses and procedures. This helps better to understand the way in which the energy transition might raise issues for landscape protection.

Yet the Eure-et-Loir planning experience remains highly ambiguous. On the one hand, it suggests, but does not prove, that the sharing of new, more situated modes of landscape representation in planning is possible. The de-centring of planner's perspective from Chartres Cathedral and the emergence of the Beauce landscape in planning shows a change in the way landscape is regulated. It shows that planning can shift from a rather solid and formal register to more open modes of representation, and so potentially allow for experiences and sensations perceived in situ to be circulated and shared in planning (breathing spaces, density, contrast, privacy). We consider this to be 'inclusive' because it induces civil servants to consider a landscape (the Beauce landscape) that, until then, had no specific monumental or patrimonial value and no existence in planning. On the other hand, this change relies on authorisation processes that exclude the public by keeping it at arm's length in order to consolidate the newly emerging aesthetic codes and planning approach.

While the case suggests that innovation may be at the core of planning experiences, it is not yet clear whether this renewal of the state-landscape is a genuine qualitative change in the local politics of landscape, or whether it will end up being a mere extension of the state-landscape (to the Beauce landscape). Everything will depend on the balance between the two dimensions (inclusive vs exclusive) that have been discussed. Lack of shared values calls for a formal closure of an emerging experience. Premature standardization of experiences through types and aesthetic codes could turn into a categorisation of

\footnotetext{
${ }^{46}$ At the end of 2006, only one public officer in the 22 regional environmental administrations agreed to meet with opponents, and he did so only in his office.
} 
landscape experiences, which would ultimately determine who has the right to speak for wind power landscapes and who has not.

3

4

\section{5}

6

\section{Acknowledgements}

The author would like to thank the French Ministry for the Environment (MEDDAD - Program PDD 'Paysage et Développement Durable'), the Conseil Français de l'Energie, the French Agency for the Environment and the Energy (ADEME) (Convention $0710 \mathrm{C} \mathrm{0019),} \mathrm{the} \mathrm{Region} \mathrm{Ile-de-France} \mathrm{and} \mathrm{the}$ Centre National de la Recherche Scientifique (CNRS - Programme Interdisciplinaire pour l'Energie) for their financial support of this research. 


\section{References}

ADEME \& Ministry of Environment (2004) Guide de l'étude d'impact sur l'environnement des parcs éoliens (Paris : MEDD).

Barraqué, B. (1985) Le paysage et l'administration, Rapport ARTE/ministère de l'Urbanisme, du Logement et des Transports. Paris, Mission de la Recherche urbaine

Bijker Wiebe E. \& Law J. (1994) Shaping technology/building society, studies in sociotechnical change MIT press.

Bishop I. D. (2002) Determination of thresholds of visual impact: the case of wind turbines, Environment and Planning B: Planning and Design 29(5), pp707 - 718

Bolinger Mark A. (2005) Making European-style community wind power development work in the US, Renewable and Sustainable Energy Reviews (9) 556-575

Bonneaud, F. (2006) Eoliennes et paysage. Bilan sur les premiers parcs installés en Eure-et-Loir, Diren Centre.

CNCE (1996) Charte du Commissaire-Enquêteur, Compagnie Nationale des Commissaires enquêteurs.

Cowell R. (2010) Wind power, landscape and strategic, spatial planning-The construction of 'acceptable locations' in Wales, Land Use Policy, 27, pp 222-232

DDE, 2006 "Projets éoliens - Demandes de Permis de Construire au 30.10.2006», Direction Départementale de 1'Equipement, octobre 2006.

Diren Centre (2005) Etude des enjeux faunistiques et paysagers liés à l'installation de parcs éoliens en Beauce. Etude conduite par l'Institut d'Ecologie Appliquée et par le Bureau d'études Laurent Couasnon.

Dupont, A. (1997) Avis $n^{\circ} 86$ - Projet de lois de finances pour 1998, adopté par l'Assemblée NationaleEnvironnement.

Ellis, G., Cowell, R., Warren, C., Strachan, P. \& Szarka, J. (2009) Wind Power: Is There A 'Planning Problem'?, Expanding Wind Power: A Problem of Planning, or of Perception?, Planning Theory \& Practice, 10(4), pp. $521-532$.

Fisher, J. \& Brown K, (2009) Wind energy on the Isle of Lewis: implications for deliberative planning, Environment and Planning A, 41(10), pp. 2516 - 2536.

Healey, P. (1997) Collaborative planning. Shaping places in fragmented societies (Vancouver: UBC Press)

Highmore B. (2011) Out of Place : Unprofessional Painting, Jacques Rancière and the Distribution of the Sensible" in : Bowman P. \& Stamp R. (eds.) Reading Rancière Critical Dissensus, Continuum Books, London- New York.

Jolivet, E. \& Heiskanen, E. (2010) Blowing against the wind-An exploratory application of actor network theory to the analysis of local controversies and participation processes in wind energy, Energy Policy, 38, pp. 6746-6754.

Kira, G. (2010) Offshore wind power development as affected by seascape values on the German North Sea coast, Land Use Policy, 26(3), pp. 185-195.

Labussière, O. (2009) Les stratégies esthétiques dans la contestation des projets d'aménagement: le milieu géographique entre singularité et exception, L'information géographique, 73(2), pp. 68-88.

Labussière, O. \& Nadaï, A. (2011a) Expérimentations cartographiques et devenirs paysagers : la planification éolienne de la Narbonnaise (France, Aude), Espaces et Sociétés, 146(3), pp. 71-92.

Latour, B. (2005) Reassembling the Social - An Introduction to Actor-Network-Theory (Oxford: Oxford University Press).

Law, J. (1992) Notes on the Theory of the Actor Network: Ordering, Strategy and Heterogeneity, Centre for Science Studies Lancaster University, On-line paper accessed June $15^{\text {th }} 2012$.

MEEDDAT (2008) Itinéraires photographiques. Méthode de l'observatoire photographique du paysage.

Marvin, C. (1988) When technologies were new: Thinking about electric communication in the late nineteenth century (Oxford: Oxford University Press).

Meyer, N.I. (2007) Learning from wind energy policy in the EU: lessons from Denmark, Sweden and Spain, European Environment, 17(5), pp. 347-362.

Möller, B. (2010) Spatial analyses of emerging and fading wind energy landscapes in Denmark, Land Use Policy, 26(3), pp. 233-241. 
Nadaï, A., Krauss, W., Afonso, A. I., Dracklé, D., Hinkelbein, O., Labussière, O. \& Mendes C. (2010) El Paisaje y la transición energética: Comparando la aparición de paisajes de energía eólica en Francia, Alemania y Portugal, Nimbus, 25-26, pp. 155-173..

Nadaï, A. \& Labussière, O. (2010) Birds, turbines and the making of wind power landscape in South France (Aude), Landscape Research, 35(2), pp. 209-233.

Nadaï, A. \& Labussière, O. (2009) Wind power planning in France (Aveyron): from State regulation to local experimentation, Land Use Policy, 26(3), pp. 744-754.

Nadaï, A. \& Van der Horst, D. (2010b) Landscapes of Energies (Guest editorial), Special Issue, Landscape Research, 35(2).

Nadaï, A. \& Van der Horst, D. (2010a) Wind power planning, landscapes and publics (Guest editorial), Land Use Policy, 27(2), pp. 181-184.

Nadaï, A. (2012) 'Planning with the missing masses: innovative wind power planning in France' in: Szarka J., Cowell R., Ellis G., Strachan P. and Warren C. (eds.) Learning from Wind Power: Governance, Societal and Policy Perspectives on Sustainable Energy, Palgrave, Mac Millan, pp280.

Nadaï, A. (2007) "Planning", "siting" and the local acceptance of wind power: Some lessons from the French case, Energy Policy, 35(5), pp. 2715-2726.

Nielsen, F.B. (2002) A formula for success in Denmark, in Pasqualetti MJ, Gipe RW, Righter RW. (eds) Wind Power in View: Energy Landscapes in a Crowded World (London: Academic), pp. 115-132.

Rabelais, F. (1534) The Very Horrific Life of Great Gargantua, Father of Pantagruel - Chapter XVI, How Gargantua was sent to Paris, and of the huge great mare that he rode on; how she destroyed the oxflies of the Beauce, Translated by Sir Thomas Urquhart of Cromarty and Peter Antony Motteux consulted at http://en.wikisource.org/wiki/Gargantua/Chapter XVI, November $21^{\text {st }} 2008$.

Rancière, J. (2000) Le partage du sensible. Esthétique et politique (Paris : La Fabrique Editions).

Sayers S. (2011) "Jacques Rancière (2004) The Politics of Aesthetics: The Distribution of the Sensible - a Review, Culture Machine Reviews, http://www.culturemachine.net/index.php/cm/article/viewArticle/190/171, accessed $15^{\text {th }}$ June 2012.

Toke, D., Breukers, S. \& Wolsink, M. (2008) Wind power deployment outcomes: How can we account for the differences? Renewable and Sustainable Energy Reviews, 12(4), pp.1129-1147.

Toke, D. (2005) Explaining wind power planning outcomes: some findings from a study in England and Wales, Energy Policy, 33(1), pp. 527 - 539.

Wolsink, M. (2010) Near-shore wind power-Protected seascapes, environmentalists' attitudes, and the technocratic planning perspective, Land Use Policy, 26(3), pp. 195-204.

Wylie, J. (2007) Landscape (London and New York : Routledge).

Zografos, C. \& Martínez-Alier, J. (2009) The politics of landscape value: a case study of wind farm conflict in rural Catalonia, Environment and Planning A, 41(7), pp. 1726 - 1744. 


\section{Acronyms}

2 ADEME (Agence De l'Environnement et de la Maîtrise d'Energie), Energy Agency.

3 DDE (Direction Départementale de l'Equipement), Departmental Road and Infrastructure Field Service.

4 Diren (Direction Régionale de l'Environnement), Regional Environmental Field Service.

5 MEDD (Ministère de l'Environnement et du Développement Durable), Ministry for the Environment

6 SDAP (Service Départemental de l'Architecture et du Paysage), Departmental Landscape and Heritage 7 Field Service.

8 WPDZ (ZDE, Zone de Développement Eolien), Wind Power Development Zone. 


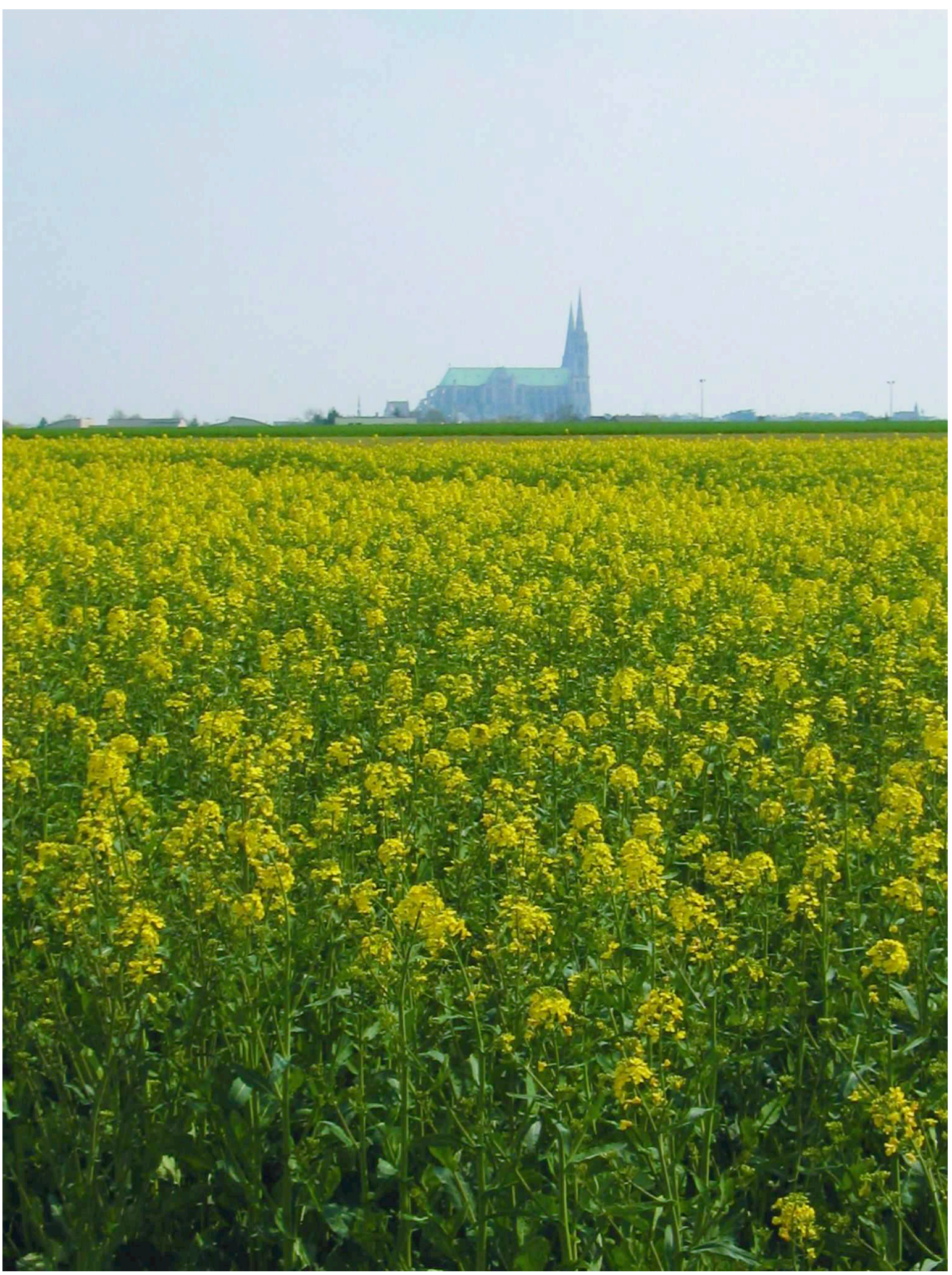

Figure 1: View on Chartres Cathedral (Picture. T. Morinière) 


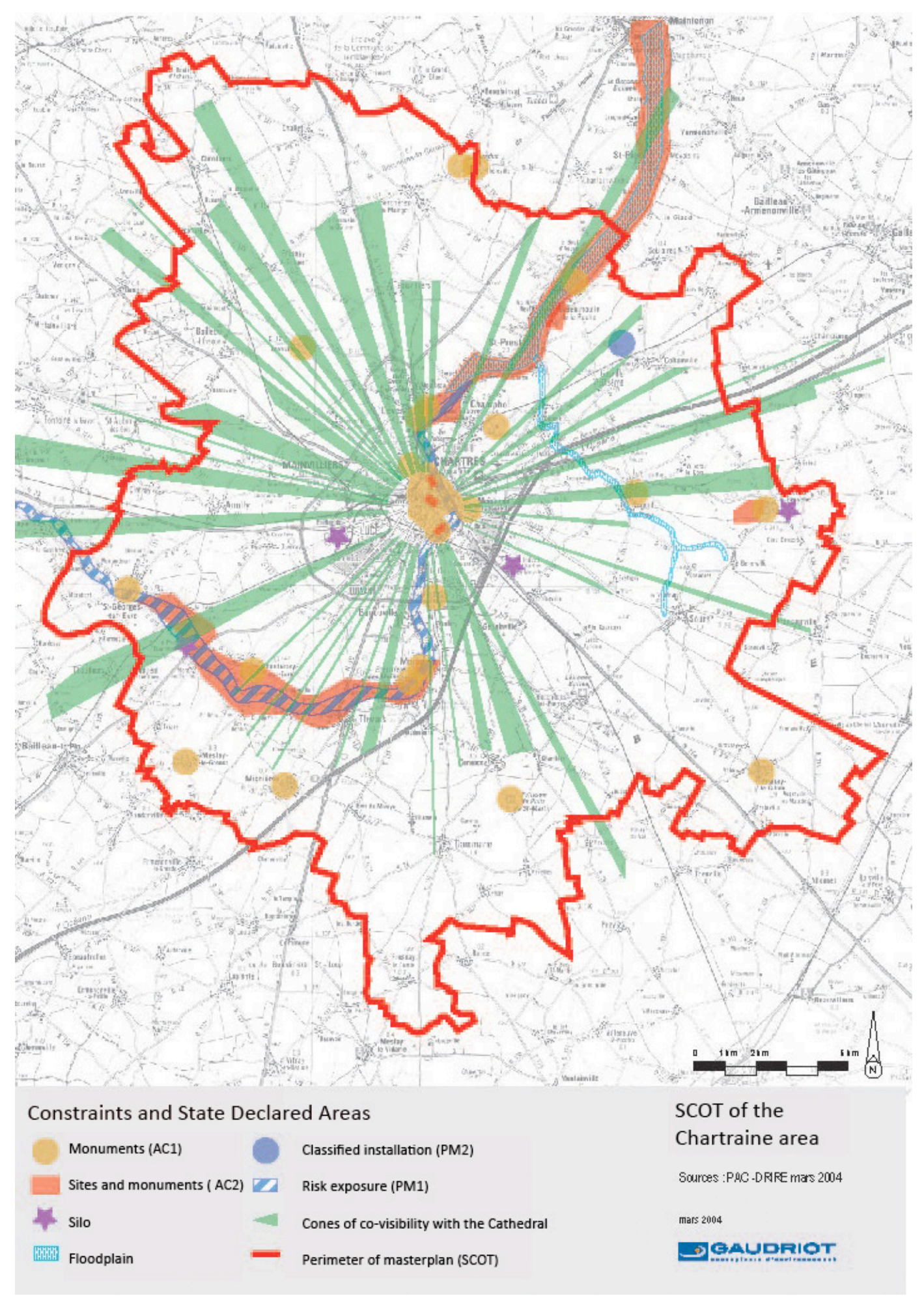

2 Figure 2: Cartographic representation of the (project of) Cathedral Directive (Source: Schéma de Cohérence Territorial de l'aire urbaine de Chartres, 2004).

4 The green radiuses represent views from and to the cathedral and were supposed to be protected against any construction project: they are illustrative of the traditional French visual approach to landscape protection. 

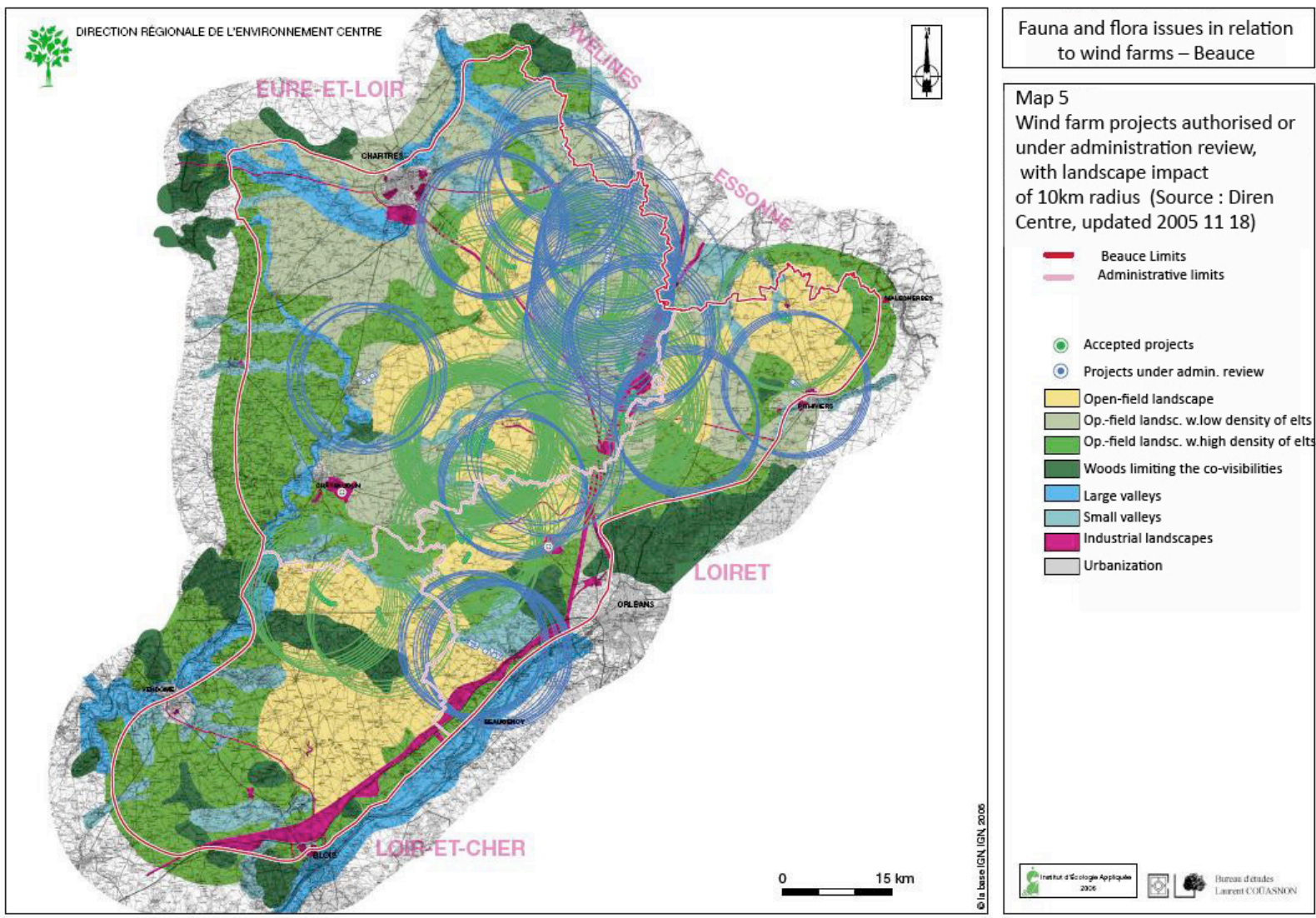

Figure 3: Wind Power Projects construction permits (accepted or under administrative assessment) (10km landscape impact radius) (Source Diren Centre, updated 18/11/2005)

5 In 2005, 44 wind projects had been granted construction permits; the local administration represented them on a map, assuming a $10 \mathrm{Km}$ visibility radius, and concluded that project authorisations and planning procedures had not properly regulated wind power development. 


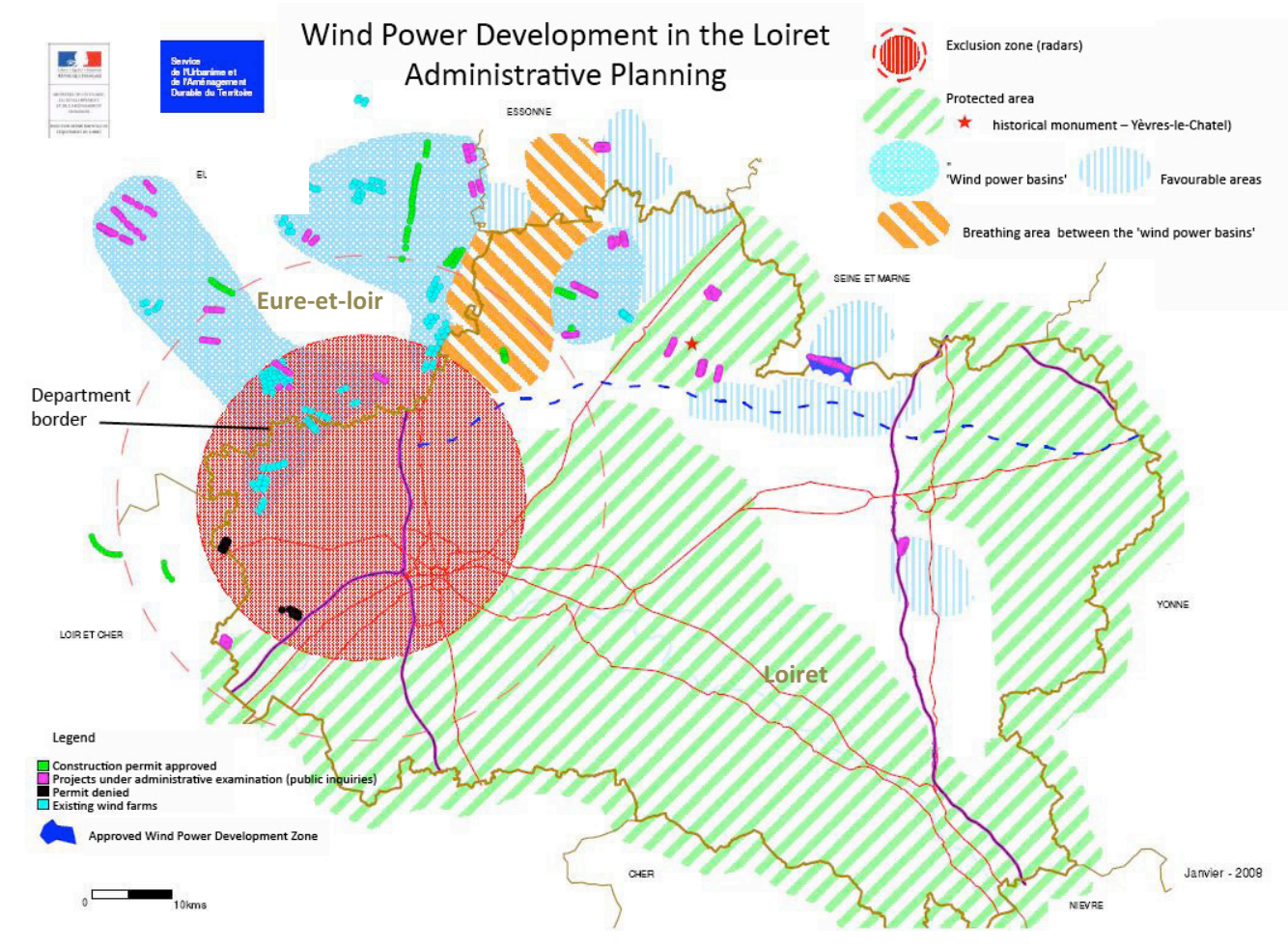

2 Figure 4: Wind Power Development in the Loiret - Eure-et-Loir Wind Power Scheme, 2008

3 The design of the Loiret planning scheme, which was concomitant with that of the Eure-et-Loir, gave the local administration with an opportunity to design wind power basins (light blue) and breathing spaces (orange stripes) which straddled the administrative border (top left of the map). 


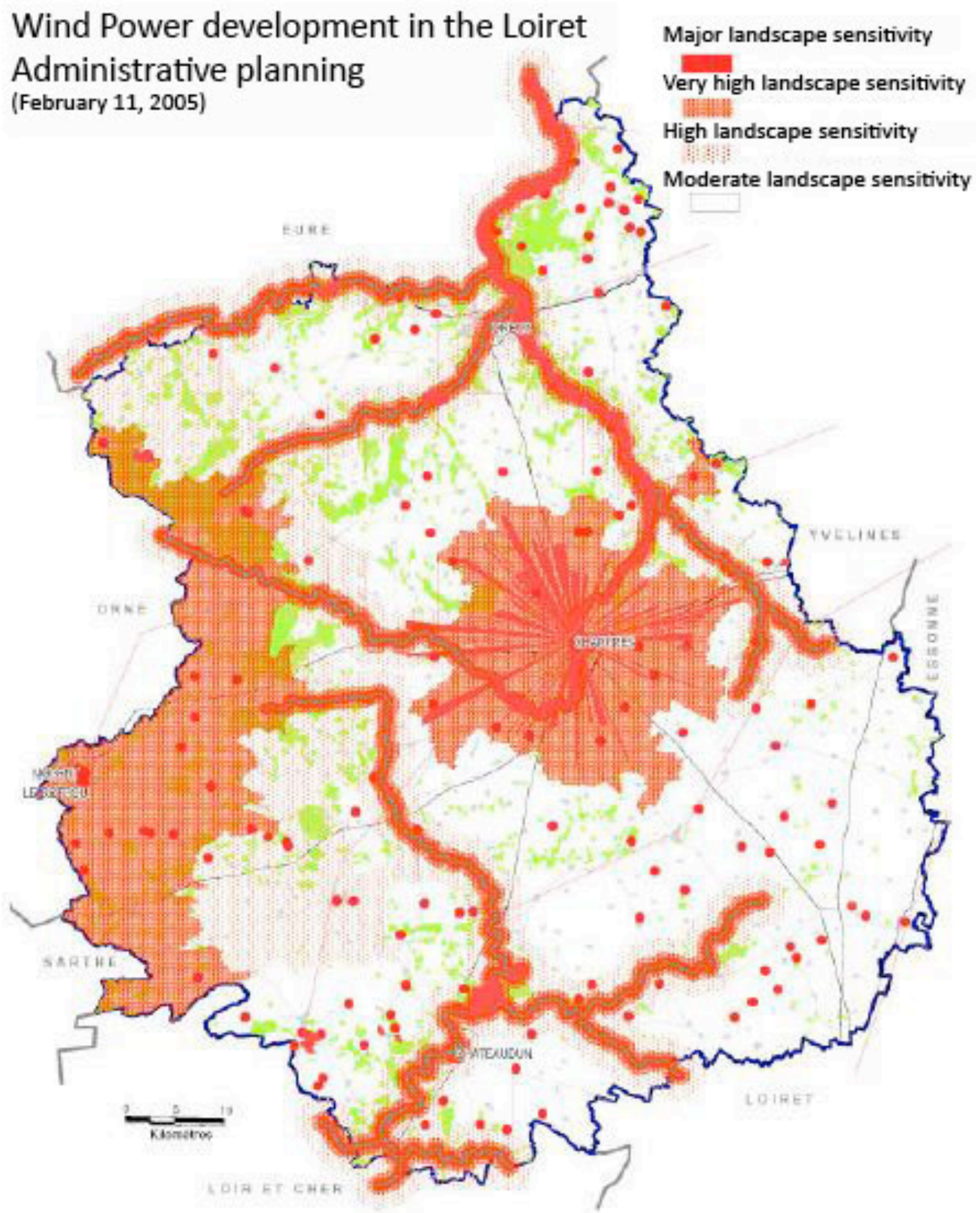

Figure 5: Landscape Sensitivity - Eure-et-Loir Wind Power Scheme, 2005

In 2005, the first wind power scheme in the Eure-et-Loir was based on a visual approach and represented zonings for visual protection following the valleys, the frontier of the regional natural park (PNR, left part of the map) and the radius of the Cathedral Directive. 


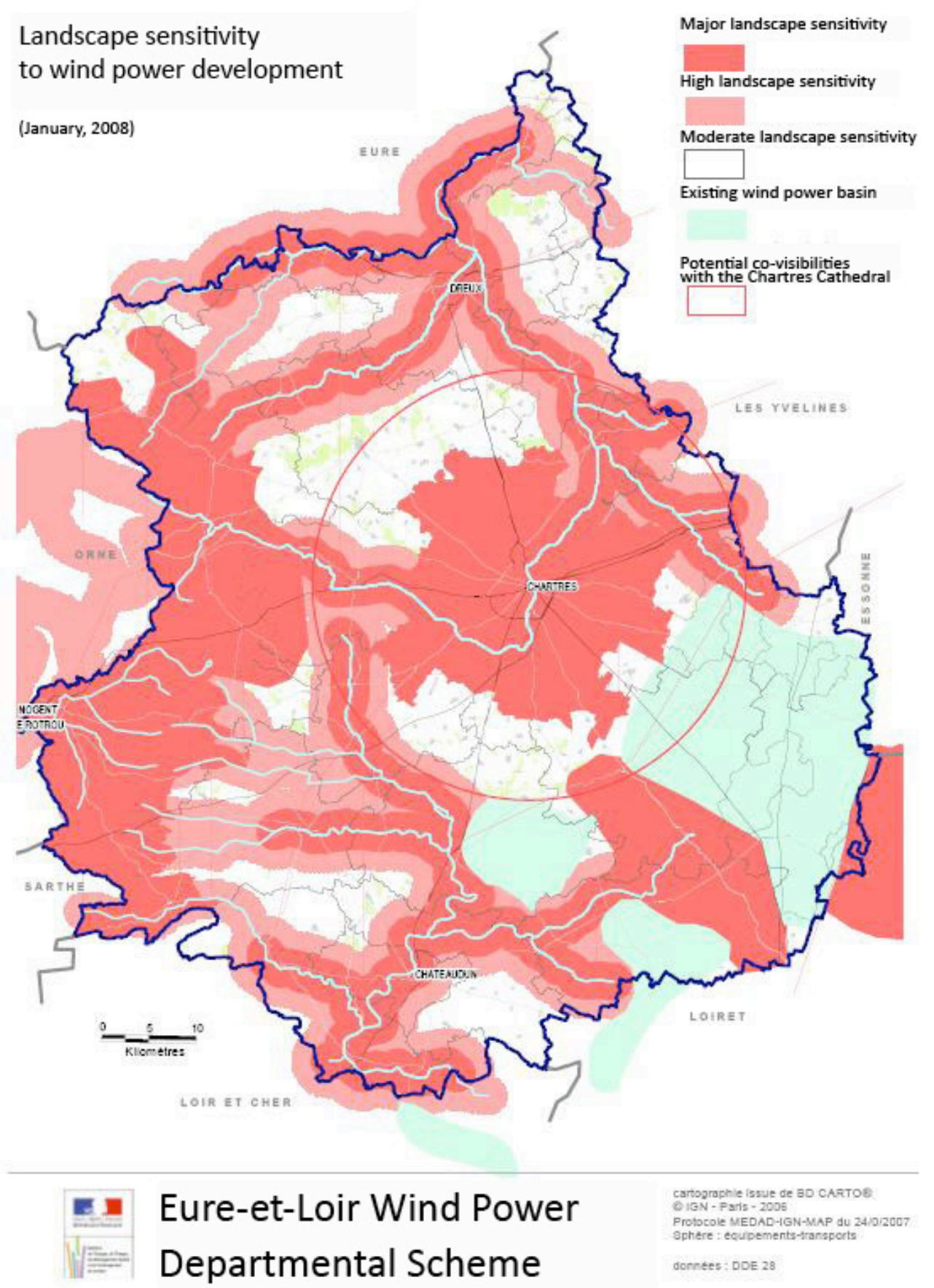

Figure 6: Landscape Sensitivity - Eure-et-Loir Wind Power Scheme, 2008

In 2008, the second wind power scheme included existing wind power basins (in light blue) and landscape sensitivities. These elements are represented by coarser graphic forms (figuring buffer zones, large circle around Chartres, in red). This is an attempt to account for the Beauce landscape and its large scale as well as to concentrate wind power development in the existing basins rather than to seek a detailed and territorial delimitation of zonings. 